yearning for peace and quiet might otherwise have persuaded many governments in the region to offer just such an assurance. But they are acutely aware that doing so would increase the internal pressure to which they are exposed from the fundamentalist Moslems their populations include. Even the schemes now in fashion for building regional security arrangements on foundations that would be acceptable in Central Europe are unlikely to succeed while the character of a government's relationships with its neighbours is determined by the changing balance of doctrinal opinion within its borders.

This is but another reason why the future of the Middle East must rest with the countries directly concerned. Certainly there is no immediate prospect that stability could be magicked out of the sand by persuading the countries of the region to become parliamentary democracies in the Western mould. Many of them are openly religious states, with the Koran (with all its freedom for alternative interpretations) standing for a Bill of Rights. So, too, are Iran and Pakistan. In circumstances like these, outsiders cannot simply say that the governments concerned should change their ways. The other side of that coin is that the burden must fall on those in the Middle East who have rightly feared bullying by Iraq (one of the most secular of Moslem states) to devise a framework for mutual relations likely to survive the strains ahead. Sadly, the Middle East may be long on oil reserves, but it is short on constructive argument. But unless it can find a prospectus for ending the holy wars that plague the region, this will not be the last high-technology war to afflict it.

\section{Farming fiasco}

Europe's amended proposals on agriculture may unblock the GATT negotiations, but have no other merits.

LIFE goes on, perhaps most conspicuously at the European Commission, which has been struggling this week on behalf of the European Communities (EC) to present the General Agreement on Tariffs and Trade (GATT) with a more enticing proposal on agriculture than was rejected last month. If the howls of protest from European farmers' organizations are a reliable index, the EC might be thought to be pointing in the right direction. But it is not. The Commission's proposals, instead of helping to place European agriculture on a rational economic foundation, would perpetuate removeable anomalies indefinitely.

None of this implies that the Commission has an easy task. That the vice in which it is trapped is of Europe's own making is not much comfort. This year, it seems likely that the cost of meeting the EC's commitments to support the prices paid to farmers will increase by no less than 26 per cent, to a total of about $\$ 40,000$ million. (The costs of storing unwanted food, or of exporting it at knock-down prices, are extra.) But the essence of the change required to let the GATT negotiations resume is that subsidies should be cut, and drastically. How to square that circle?

The Commission's first attempt is a recipe for winning the worst of all worlds. Support prices would be drastically reduced - by as much as 40 per cent in the case of cereals, for example - which would have the effect of making some export subsidies unnecessary. But it is also proposed that there would be arrangements to make sure that small farmers would be at least partly protected from the effects of these changes on their pocket-books. Farmers on a grander scale, on the other hand, would be paid for taking land out of production. One consequence of the proposed changes would be to replace direct price supports by compensatory payments of other kinds. Farmers of all sizes accurately guess that they would be worse off. But another consequence would be a general reduction of the efficiency of European farming.

The reasons why the EC consistently (and perversely) puts the cart before the horse on European farming derive from the Treaty of Rome, and from the belief which it enshrines that farmers should not be relatively impoverished by the great industrial resurgence then foreseen. In the event, agricultural technology has made the most dramatic advances in the past forty years, with the result that Europe is grossly over-farmed. Schemes for encouraging exotic crops will take up only a little of the slack. At some stage, Europe will have to bite the bullet of persuading farmers to do something else. Compensating them for the social upheaval entailed in doing something else would be proper. Paying them to be inefficient is, by comparison, foolish and probably self-defeating, for farmers are an ingenious lot.

\section{Inventive Britain}

The British government's decision that the British Technology Group should be sold marks the end of an era.

THE British Technology Group (BTG) is the residuary legatee of two brave ideas, represented by the National Research Development Corporation and the Industrial Reconstruction Corporation (IRC). The first, created immediately after the Second World War, was meant to turn into commercial reality the supposedly wasted bright ideas of British researchers. It has done useful work in the sponsorship of bridge-building, the manufacture of antibiotics (cephalosporins) and even the construction of hovercraft. But, while often seeming to researchers to be a friendly uncle, it could not play that role to all would-be dependents and inevitably came to seem to be just another venture capitalist. IRC, invented by the second postwar Labour Government, was always more controversial. It was designed to be a coercive industrial marriage broker. In each case, the idea was that the government would put industry to rights. It says much for BTG that it has survived in a changed climate and yet remained saleable. 